\title{
新潟県の地すべり地における土の性質 \\ Characteristics of Soils of Landslide Areas in Niigata Prefecture
}

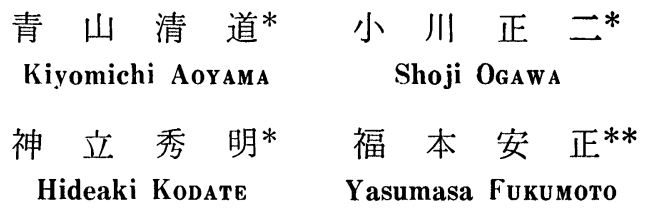

\begin{abstract}
Niigata prefecture, it is well known as the occurence areas of landslides in Japan. Most of these landslides concentrate on south-western parts of the prefecture. Every year, extensive damages have been inflicted in these parts by disaster of landslide. Therefore, countermeasure for preventing such disaster must be done urgently.

For discussing stability of slopes in landslides areas, it must have full knowledge of soil properties in soil engineering aspect in these places. However, the investigation and research from soil engineering point of view are not sufficient.

The accumulated data obtained at various locations in Niigata prefecture are analyzed, and some soil properties of landslide areas are made clear. Moreover, the tests based on soil engineering aspect were performed and a few important facts can be detected.
\end{abstract}

\section{1. はじめに}

新潟県は全国でも有数の地すべり多発地带であり，そ の大部分は県の南西部に集中している。特に, 頸城地方 では，每年多くの地すべりが発生している。地すべり地 での災害事故は多く，その防止対策は早急になされなけ ればならない。

地すべり地の安定性を定量的に検討するためには, 地 すべり地の土の性質を土質工学的な観点からも調査・研 究を進めなければならないが, 過去の調査・研究が土質 工学的に行わ机た例は比較的少ない。

ここでは新潟紧下の地すべり地の土質特性を知るため の手はじめとして, 過去に行われた, 地すべり地域約70 個所, ボーリング地点数にして約 1,000 個の地質調查, 土質調査の結果をまとめ, 少ない資料ではあるが、これ らを統計的に処理し，若干の考察を行った。また，笑際 に地すべり地の試料を採取し，土質実験を行い，セン断 特性を中心として考察を加えたので，その概要について 報告する。

\section{2. 地下水位面と地すべり面}

過去に行われた地すべり地の調査報告書にもとづい て, 地下水位面と地すべり面の深さの度数分布 ${ }^{11}$ を示す と, Fig. - 1, Fig-2のようになる。すなわち, 地下水位

*新潟県大学工学部 土木工学教公

**新潟県農林部 治山課
面はその大部分が地表面より $0 \sim 4.0 \mathrm{~m}$ の範囲にあり， 特に、地表面下 $1 \mathrm{~m}$ 以内である場合が全体の約 $25 \%$ を占

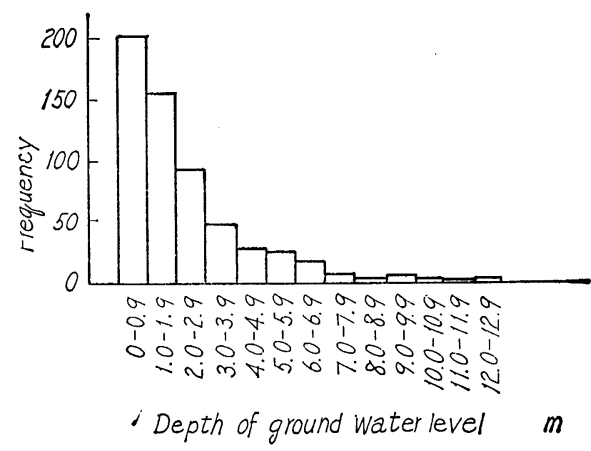

ig. -1 Frequency distribution of depth of ground water level

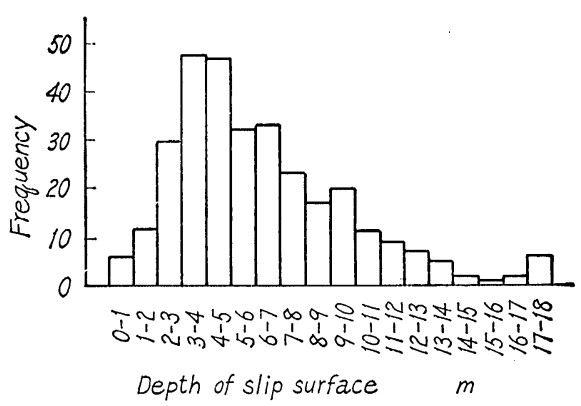

Fig. -2 Frequency distribution of depth of slip surface 
めている。また，地すべり面は $2.0 〜 10.0 \mathrm{~m}$ の範囲にそ の大部分が存在していることがわかる。

地下水位面と地すべり面との関係は，Fig. -3 のよう になり，地すべり面はほとんど地下水位面以下にあるこ とになる。しかしながら，地質調查，土質調査報告昦に 記截されている地下水位面はボーリング時の孔内水位で ある場合が多く，ボーリングを実施する場合，一般に不 透水性のベントナイトを使用すること，また，ボーリン グ調查を实施した時期が地すべり時と一致しているか不 かは不明であるので，季節に関係なく地すべり面が地下 水位面より深い位置にあるとはいいがたい。特に，地す べりの発生件数が Fig. -4 亿示すように融雪期, 集中豪 雨時にかたまっていること, 地すべり地の土に吸水させ てセン断実験を行らと吸水させない場合に比して，七ン 断強さが低下することを考劣あわせると，Fig. - 3 の関 係が不遍的であるとはいいがたい。したがって,この点 については，今後地すべり地域に拄いて，地下水位変化 と地すべりの移動とを関連づけて観測を継続しなければ 結論を出すことはできない。

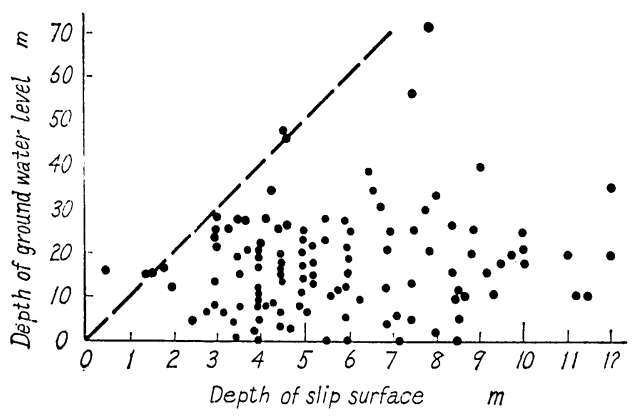

Fig. -3 Relation between ground water level and depth of slip surface

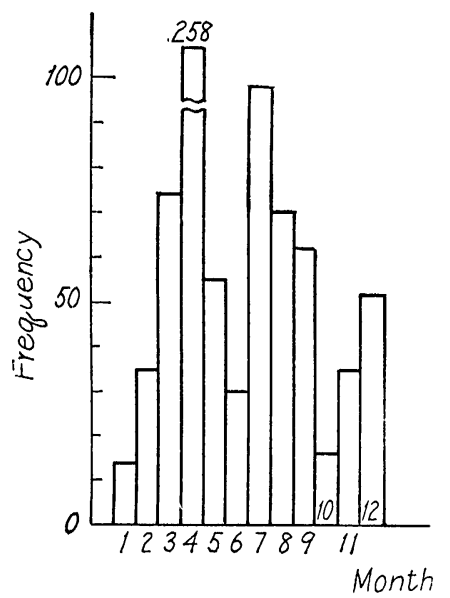

Fig. -4 Monthly number of occurence of landslides

\section{3. 地すべり面と基岩の地質}

地質，土質調査報告書にもとづいて，地すべり面付近 の地質を調べてみると Fig. -5 のようになる。これより 地すべり面付近の地質は大部分は粘土, 風化泥岩, 碩混 り粘土に属している。一方, 地すべりを生じていない基 岩の地質は, Fig. -6 に示したように泥岩, 頁岩, 砂岩 が大部分を占めている．地すべり土と基岩の相関性につ いては, Fig. -5, Fig. -6 上り風化泥岩と泥岩の関連性以 外，基岩が風化したために地すべり層になったと考える 根拠となるものは少ない上らである。特に，基岩では砂 岩がかなり多いのに対して，すべり層には砂質土がほと んどないことなど, 地すべり面付近の土と基岩の土の地

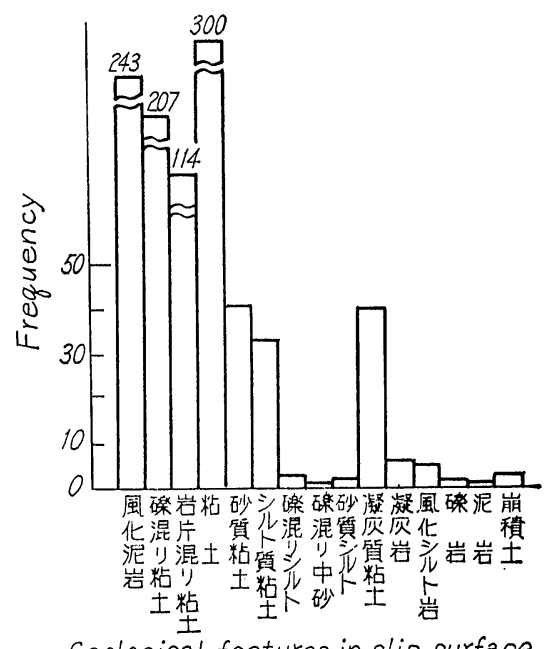

Geological features in șlip surface

Fig. -5 Frequency distribution of geological features in slip surface

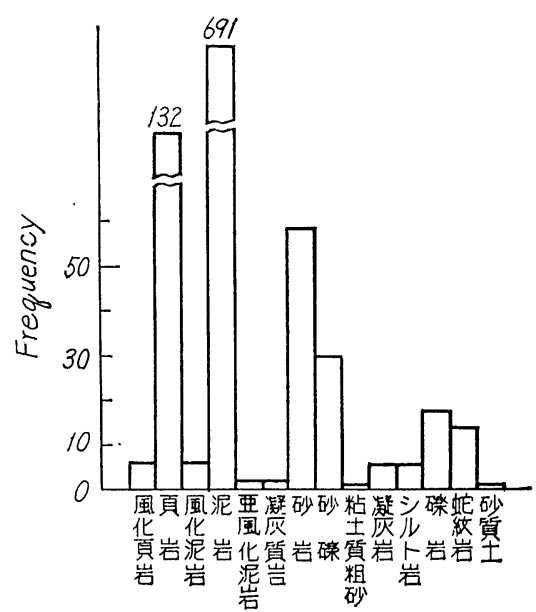

Geological features in bed rock

Fig. -6 Frequency distribution of geological features in bed rock 
質の相関性については必ずしも明白にされているとはい いがたい。

\section{4. 地すべり地の土質特性}

地すべり地の土質特性を把握するために過去の調査資 料をもとに，地すべり面内，地すべり面外の土の物理的 性質, 力学的性質についてまとめてみた。ただ，地すべ り面を確認することは特殊な場合を除いて難しいので,

一概にそれを決定することは容易ではないが，ここでは 一応，調查資料に記されたものを参考にして次のように 分類した。

(a) 地すべり面内の土：調査報告書にすべり面と記載 されているもの，あるいはすべり面と判断される もの。

（b）地すべり面外の土：調查報告畫に打いて，同一個 所ですべり面と記載された以外のもの，あるいは すべり面と判断することが困難なるの。

(i) 物理的性質

前記のような分類をして，地すべり地の土の自然含水 比, 液性限界, 飽和度の頻度分布を示すと, それぞれ,

Fig. -7 , Fig. -8 , Fig. -9 のようになり，土の物理的 性質は地すべり面付近でも，それ以外でもほとんど変ら

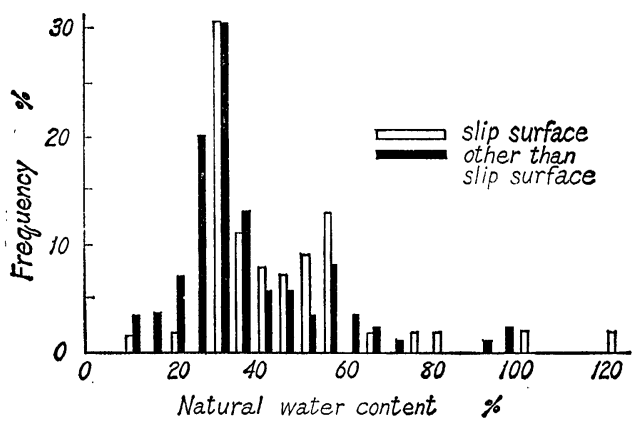

Fig. -7 Frequency distribution of natural water content

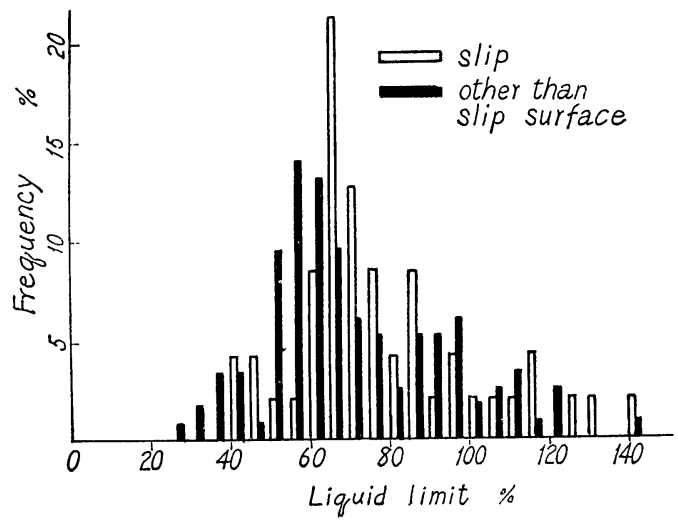

Fig. -8 Frequency distribution of liquid limit

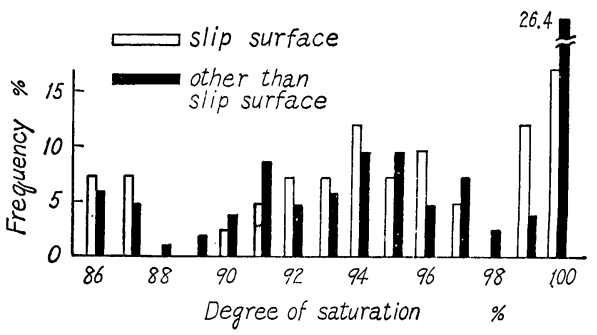

Fig. -9 Frequency distribution of degree of saturation

ないといえる。また，飽和度はほぼ90\%以上と高いが， 自然含水比は液性限界よりかなり低い傾问がみられる。 実際に地すべり地の土の自然含水比を測定してみると, 液性限界よりも低く，むしろ塑性限界に近いものが多 く，流動しにくい状態にあるよらに思われる。しかしな がら, Fig. -11 Fig-12 に示したよらに粘着力, 内部摩 擦角から判断するとセン断抵抗力が非常に小さい。また， 飽和度が90\%以上になっていることを考え合せると，こ のような関係は不自然である。この原因としては土質試 験法が考えられる。

(ii) 自然含水比の修正 ${ }^{2}$

（JIS A 1205），（JIS A 1206）にもとづいて液性限界 や塑性限界を求める場合, 試料土をときほぐし標準網 ルイ $420 \mu$ を通過した粒径の土だけで実験が行われるの に対して, (JIS A 1203) で自然含水比を求める際には, 特別大きな粒径の土は除くにしても， $420 \mu$ 以上の粒子 も含めて行われており，両者は異なる粒径範囲の土を扱 っていることになる。

しかしながら、土粒子の保水能力は粒径によって異な るので, 粒径による含水比の相違を考慮する必要があ る。いま,これらの修正を次のように行って, $420 \mu(0.42$ $\mathrm{mm}$ ) 以下の粒子の自然含水比を求めてみる。

全体の自然含水比を $w_{0}, 0.42 \mathrm{~mm}$ 以下の粒子の自然 含水比を $w_{1}, 0.42 \mathrm{~mm}$ 以上の粒子の自然含水比を $w_{2}$, 液性限界を $w_{l}$ とし, 各々の部分の土粒子の重量を $W_{0}$, $W_{1}, W_{2}$ とすると,

$$
W_{0} \cdot w_{0}=W_{1} \cdot w_{1}+W_{2} \cdot w_{2}
$$

となる。したがって, $0.42 \mathrm{~mm}$ 以下の粒子の自然含水比は,

$$
w_{1}=\frac{W_{0}}{W_{1}} w_{0}-\frac{W_{2}}{W_{1}} w_{2}
$$

となる。ただし， $W_{0}=W_{1}+W_{2}$ である。

粒径加積曲線より, $W_{0} / W_{1}, W_{2} / W_{1}$ が求まるから, $0.42 \mathrm{~mm}$ 以上の粗粒子の保水量が決まれば，(2)式によっ て, $0.42 \mathrm{~mm}$ 以下の粒子の自然含水比が求まる。この $w_{1}$ と $w_{l}$ とを比較すれば, 自然状態の土の含水比が流 動曲線に対してどのような関係にあるかが明白になる。

いま, 砂の最大保水量を考虑して, $w_{2}=15 \%$ と仮定し て，自然含水比を修正した一例を示すと Fig. -10 のよう になり，0.42mm 以下の土粒子の自然含水比は液性限界 


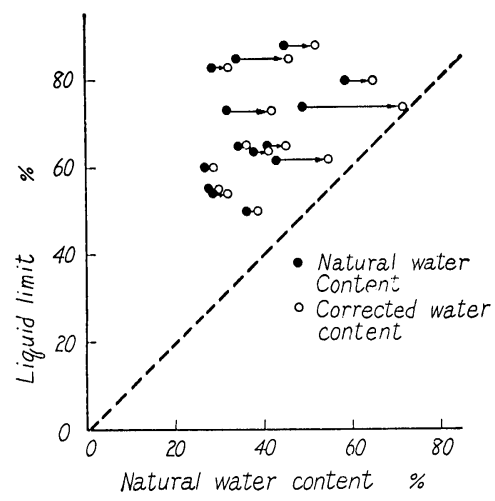

Fig. -10 Relation between natural water content and liquid limit

にかなり近いものであることがわかる。

一般に、士は自然含水比が塑性限界に近い㑲を示す場 合には硬所でセン断抵抗力が大きく，安定して招り、液 性限界に近い値を示寸場命には拌弱で，わずかの乱れを 与えても流動的となり不安定である。

このよ5に, 自然含水比と液性限界, 塑性限界との相 互関係は土の力学的性貿とも密接な関係があるので, 地 すべり地の土に適した土質試験方法を確立する必要があ る。

\section{(iii) 力学的性質}

粘着力, 内部摩擦角, 鋭晸比についても同様にして, 度数分仍を示すとそれぞれ, Fig. -11, Fig. -12, Fig. -13 のよらになる。ここで，特に注目すべきことは，大部分 の土の哾敏比が 2.0 以下であり，なかでも 1.0 以下のも のがかなりの部分をしめているということである。

このよらなことの原因としては，まず試料採取時の乱 れの影響が考えられる。しかし，一般には，鋭敏比は練 り返した土の強さを基準としているので，ごく特殊な土 を除き，たとえどのように乱されていても鋭敏比が 1.0 以下になることはないはずである。つぎに考えられるこ

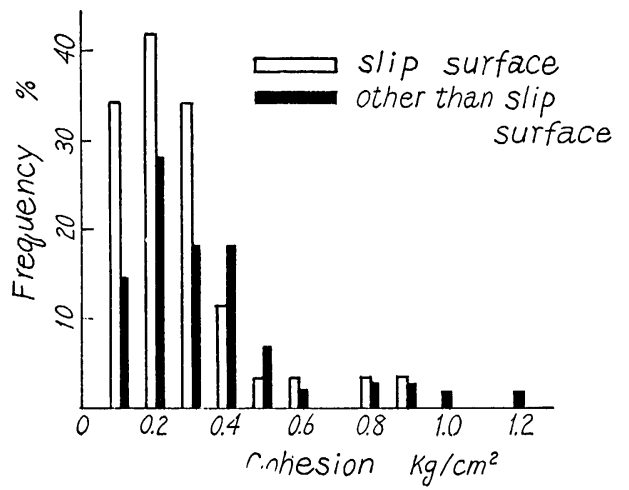

Fig. -11 Frequency distribution of cohesion of soils

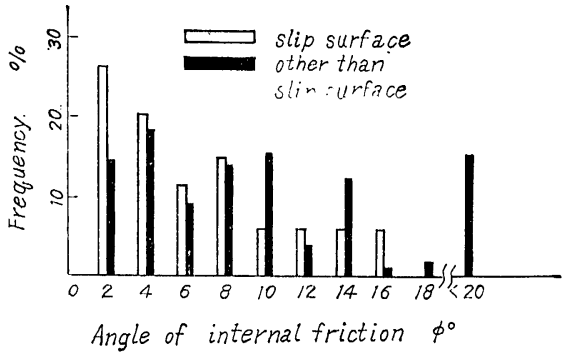

Fig. -12 Frequency distribution of angle of internal friction

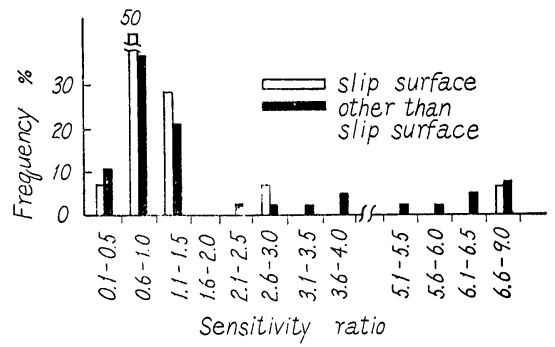

Fig. -13 Frequency distribution of sensitivity ratio

とは，地すべり地の土には潜在的に溦少クラックが発渞 していることである。このことは土をよく觀察すれば容 易に確認しらるものである。したがって，乱されていな

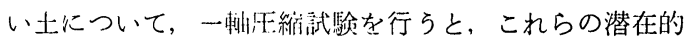
なクラックに沿ってすべりが発先して, 王繀強さはかな り小さくなる。一方, 練り返した土は, これらの潜在的 クラックを人工的に排除したものになるので, 変位咀も 大きいが、正縮強さも大きくなると考えられる。

いずれにせよ，Fig-13 が正しいとするならば，新潟 紧南西部の地すべりは，すでに過去に扣いて何回か，地 すべりを生じたものであるか，旧崩積土か，あるいは現 在，相当量の移動をらけているかであるといえよう。

\section{5. 地すべり地の土のセン断強さ}

上記のことを確認するために，実際に地すべり地域よ り, シンウォール・サンプラーで試料を採取し，以下の ような各種のセン断舁験を行った。

(i) 一軸圧縮試験 ${ }^{3}$

東頸城郡牧村の地すべり地域より試料を採取し，一軸 日縮試験を行い，その結果から，応力一七ズミの関係を 描いたものが Fig. -14, Fig. -15 である，Fig. -14 の試 料（A試料，含水比 $w=65 \pm 5 \% ，$ 湿潤密度 $r_{t}=1.57$ $\left.\pm 0.03 \mathrm{gr} / \mathrm{cm}^{3}\right)$ は自然に形成された肖格檏造をそのまま 保って扣り、含水比を変えないで練り返すことにより, この構造が破壊されて圧縮強さが著しく低下しているこ とがわかる。 


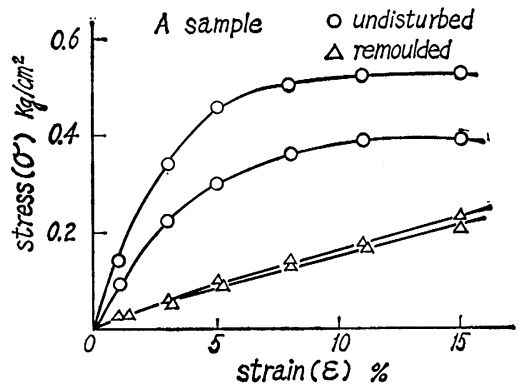

Fig. -14 The stress-strain curves obtained from unconfined compression tests (A sample)

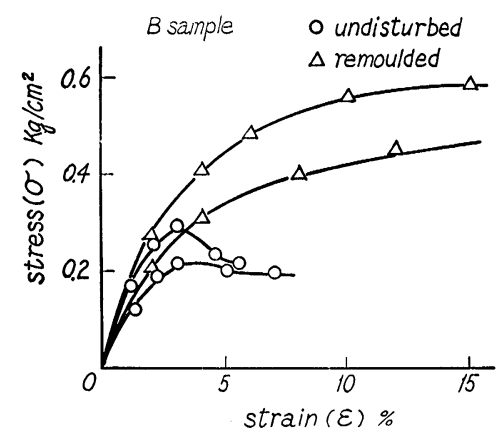

Fig. -15 The stress-strain curves obtained from unconfined compression tests (B sample)

これに対して Fig. -15 の試料（B試料, $w=35 \pm 2 \%$, $\left.r_{t}=1.68 \pm 0.02 \mathrm{gr} / \mathrm{cm}^{3}\right)$ は練り返しにより, 逆に圧縮強 さが増加する傾向がある。

土の骨格構造の破壊による強さの減少の程度を表わす ための鋭敏比の定義は Terzaghi と Tschebotarioff の提 案した二通りの方法がある。いま, Terzaghi の提案した 方法により鋭敏比を求めてみると, B 試料の鋭敏比は 1 より著しく小さいことがわかる。一連の一軸圧縮試験よ り得られた破壊七ズミの度数分布が，かなりのバラッキ を示していることから，前に述べたような理由で，この 試料はすでに過去に乱されており, 内部に亀裂が発達し ているすのと考えられる。

(ii) 含水比を変化させない場合の一面セン断試験

この事実をいっそうはっきりさせるため， $\mathrm{A}$ 試料， $\mathrm{B}$ 試料について次のような三通りの方法で一面セン断試験 を実施した。

（1）乱さない状態での一面セン断試験

(2) 乱した状態での一面セン断試験

（3）練り返した状態での一面セン断試験

ここで, 乱した状態とは微少単位の土の構造が破壊さ れない程度に自然に形成された構造を破壊した場合であ り, 地すべりの生じているときには，土の応力ーヒズミ 曲線の最大セン断強さに達して, 土が破壊したときに相 当する。
また，練り返した状態とは土を約10分間充分に練り返 した状態である。粘性土に括いては練り返しの回数の增 加にともなって強度は低下し，1 分間 30 回の割合で 300 回練り返すと一定値に達するとの研究結果4)による ものである。これは, 大変形を受けて, 過去の応力履歴 が全く失われた状態に相当する。

A, B の試料に対して, セン断応力と水平変位との関 係を垂直応力をパラメーターとして示すと，それぞれ， Fig. -16, Fig. -18 のようになり, セン断応力と垂直応 カとの関係は Fig. -17, Fig. -19 のようになる。

$\mathrm{A}$ 試料のような自然構造の発達した粘性土では, わず かの乱れを与えてもセン断強さが低下する。これをさら に自然含水比のままで充分に練り返すと, 構造が乱され ないときに比へ，七ン断強さはさらに低下していること がわかる。また，この状態ではセン断強さのピーク值と 最終值がほとんど変らなくなる。

A 試料のような自然構造の発達した粘性土では Fig. 16 に示したように $a, b, c$ をそれぞれ(1)，(2)，(3)の状 態で試験を行ったときの一定の垂直応力のもとでのセン 断強さとすると $a>b>c$ の関係にある。

B試料については, Fig. -18 に示すよ5に, 自然状態 のままセン断試験を行っても，人為的に乱した後に試験 を行っても，七ン断強さはほとんど同じである。これは

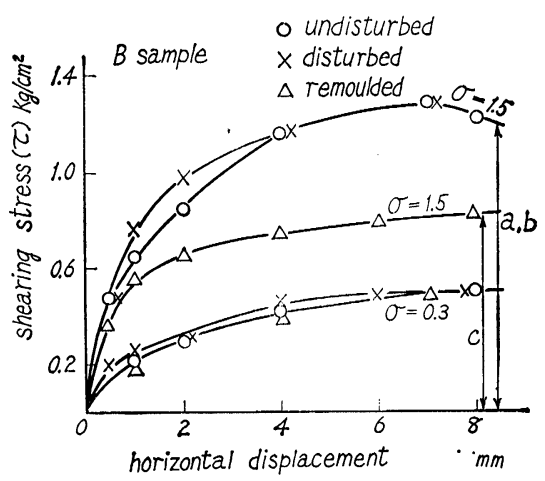

Fig. -16 Results of direct shear tests (A sample)

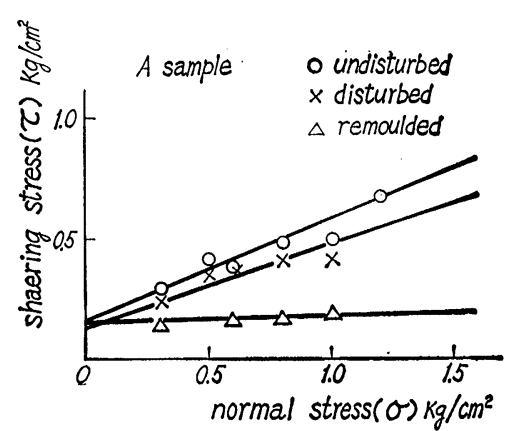

Fig. -17 Relation between shear stresses and normal stresses (A sample) 


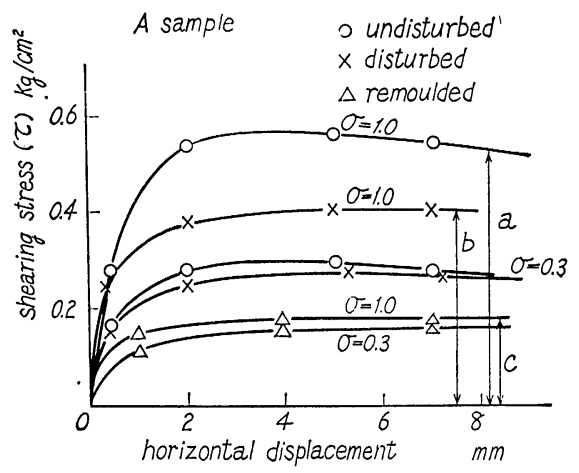

Fig. -18 Results of direct shear tests (B sample)

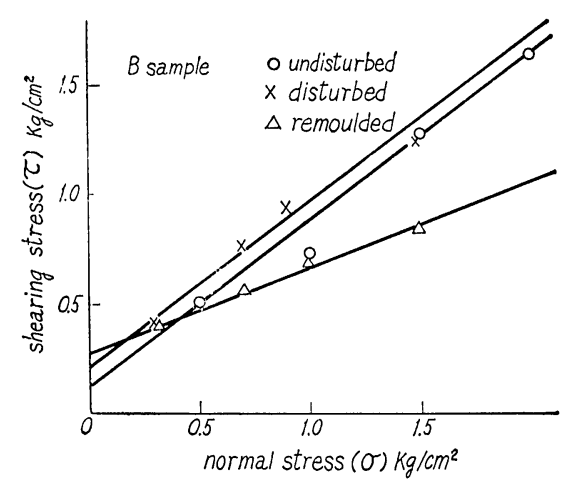

Fig. -19 Relation between shear stresses and normal stresses (B sample)

明らかに，B試料が過去に拈いて乱された状態におかれ ていたことを示すものである。これを充分練り返した 後, セン断試験を行うと, セン断強さの低下はあるが, その低下の割合は $\mathrm{A}$ 試料ほどではない。これより, 過去 に乱された状態にある B 試料のような土のセン断強さは $a \geqq b>c$ の関係にある。

このような関係をみると，A試料のよらな土はかく乱 によって, 急激にセン断抵抗力が低下し, 急激な崩壤を 生じる可能性があるといえる。

(iii) 含水比を変化させた場合の一面セン断試験

しかし, 篲者らが県内の地すべり地の土についての土 質夷験を行った籁囲でも，B試料のようなセン断特性を 示す土がかなり多いことから，比較的緩慢に生じている 地すべりは旧地すべり崩壊土が再びすべっているのでは ないかと思われる。

いずれにしても, 地すべりの発生は含有水分の量の変 化が関係していると考えられ, 潜在的な微少クラックの 発達している土が吸水したときにはセン断強さの低下は 大きいものと考えられる。Fig. -3 をみると，地すべり 面はほとんど地下水位面以下にあると考えられるので, これらのことを考虑して, 自然土に吸水させて, 前述の 乱さない状態, 乱した状態, 練り返した状態でセン断実
Table-1 Results of direct shear tests

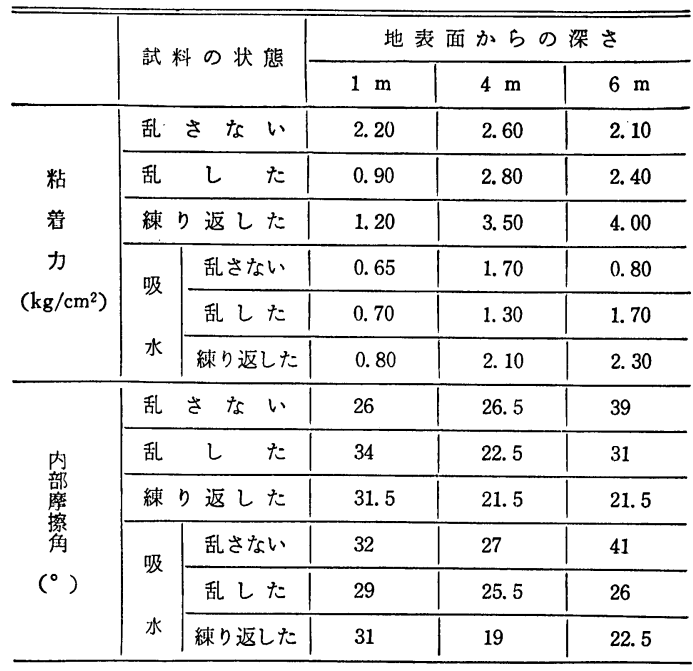

験を行ってみた。

中頸城郡清里村，東戸野地すべり地域の土を吸水しな い場合と吸水させた場合の条件で一面セン断試験を行っ た結果を Table-1 に示す。この地すべり地の土は吸水 させないとさは乱さない状態, 乱した状態, 練り返した 状態のいずれの場合にもセン断強さがほぼ同じであるこ とがわかる。しかしながら，同じような状態で吸水させ るとセン断強さが低下する。

このよ5に吸水することによってセン断強さが低下す ることと，Fig.ー3に示されているようにすべり面が地 下水位面以下にあることを考えると, 地すべり地の土の セン断さを調べる場合には，吸水させた試料について実 験を行らのが望ましいといえる。

\section{6. おわりに}

以上，新潟県の地すべり地に打ける土の性質について 若干の結果を述べたが，これらを要約すると次のように なる。

1）鋭敏比が大きく，補正した自然含水比が高い土よ りなる地すべりはかなり急激な崩壊を生じる可能性 がある。

2）鋭敏比が 2.0 以下，特に 1.0 以下のような土は潜 在的な微少クラックが存在して括り, すべりが発生 すると自然状態での粒子構造が破壊されて, むしろ セン断抵抗力が增大する。しかし, 変位量も增大寸 る。したがって，このような場合の地すべりは緩慢 に進行するものと思われる。

3）地すべり地域の土が潜在的な微少クラックを含ん でいること，鋭敏比が小さい場合が多いことを考え ると，新潟県下の地すべりは過去に执いてすでに何 回か地すべりを生じているか, 旧崩積土である場合 が多いと考えられる。 
4）長期間にわたって生じる地すべりについては， Skempton ${ }^{5)}$ の提案しているようにセン断強さのピー ク值をそのまま用いず残留強さ6),7)を用いることな ど地すべり地域に適した土質試験方法の確立を急が なければならない。

末筆ながら，過去の地質，土質調查資料の収集に御協 カいただいた新潟県治山課, 砂防課, 土木課の関係各 位，地すべり地域の調查に御協力いただいた建設省土木 研究所新潟試験所, 試験採取に御協力いただいた関係会 社の各位に深甚なる謝意を表します。なお，この研究の 一部は文部省科学研究費昭和 $47 \sim 49$ 年度自然災害特別研 究(1)及び昭和50年度文部省科学研究費試験研究(2)の補助 を受けて行われた。ここに深謝いたします。

\section{参 考 文 献}

1）小川正二, 青山清道, 福本安正：“新潟県の地スベリ地に
おける土質特性” 土木学会, 第 1 回関東支部年次研究発表 会講演概要集 (1974 年)

2）小川正二, 青木滋, 福本安正 : “新潟県南部の地すべり地 の土質について”第10回災害科学総合シンポジウム講演論 文集（1973年）

3）小川正二, 青山清道：“新潟県の地スヘリリ地における土の 力学的特性” 第 9 回土質工学会研究発表会講演集 (1974年)

4）土質工学会試験法改訂委員会編集 :「土質試験法」p. 352 （土質工学会, 昭和43年版）

5) A. W. Skempton: "Long-term Stability of Clay Slopes" Geotechnique（1964年）

6）小川正二, 青山清道, 平岡考夫, 佐合裕治 : “リングせん 断による粘性土の力学的性質に関する実験”第11回災害科 学総合シンポジゥム講演論文集（1974年）

7）青山清道，小川正二，沢崎雅之，平岡孝夫：“地スペリの 力学的解析に関する一考察” 地すべり学会第13回研究発表 会 (1974年)

（原稿受理日 昭和51年 1 月20日）

\section{第 5 回岩の力学国内シンポジウム講演募集}

1964年に第 1 回岩の力学国内シンポジウムが開催されてょり，回を重ねる毎にますます盛会で活発化したこのシン ポジウムも，本年度は第 5 回を迎光，下記のように東京で開催されることになりました。

今回からはこのシンポジゥムの内容を一層高めるため土木学会・土質工学会・日本材料学会·日本鉱業会に限らず 岩の力学に関連するその他の学協会の会員からもご応募頂けるよう協賛を报願いいたして抣りますので,どなたでも 応募下さいますよらご案内申上げます。

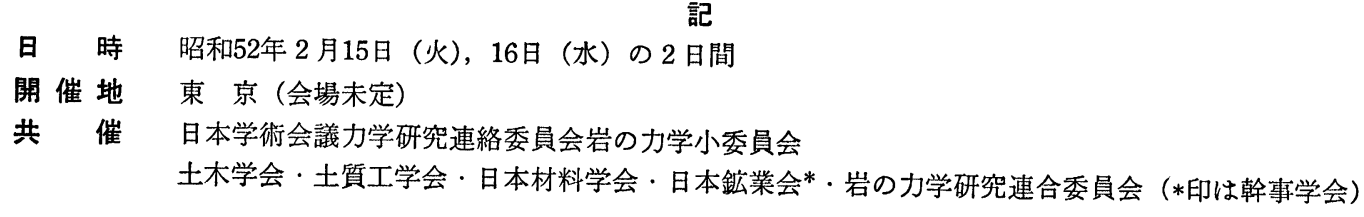

1. 発表論文の内容 : 下記テーマに関するもの

\section{一発 表 論 文 募 集 要 項一}
(1) 岩石および岩盤の性質
(2) 岩艋の現位置計測
(3) 試験值と工事実績との対比
(4) 山はね和よび破壊音

2. 応募方法: 論文発表希望者はB 5 判用紙に「第 5 回岩の力学国内シンポジゥム講演申込み」と題記し,つぎの a) 〜f）までの 6 項目を必ず記載して下記 8 . へ申込んで下さい。
a) 講演題目,
b）講演者（複数の場合は実講演者に○印）,
e ） 申込者の氏名, 連絡先住所拈よび電話番号,
f ) 別刷の要否
c）勤務先,
d）所属学会

また，申込みと同時に 400 字以内の要旨を必ず添付して下さい。

3. 申込締切：昭和 51 年 9 月 30 日（木）必着

4. 論文の採否 : 申込論文の採否は, 本シンポジゥム運営委員会にご一任下さい。 採否決定後直ちに応募者に通知いたします。

5. 論文提出締切：昭和51年12月15日（水）必着

6. 論文の体裁：原稿は，所定原稿用紙に執筆要項にしたがって和文タイプして下さい。原稿の長さは所定用紙 5 枚に，英文要旨 A 4 判 1 ページとします。

7. 講 演 集: 発表論文は提出された原稿をとのままオフセット印刷します。 な技，別刷は今回から実費を申受けますので，必要部数を申込みの際，明記して打いて下さい。

8. 申 込 先: $\tau 104$ 東京都中央区銀座 8-5-4 社団法人 日本鉱業会内

「第 5 回岩の力学国内シンポジゥム運営委員会」＼cjkstart電話（03） 572-5091 


\begin{tabular}{|c|}
\hline $\begin{array}{l}\text { 最近の茶臼山地すべりの移動特性 } \\
\text { 「地すべり」Vol. 13，No. } 2 \text { (通巻第46号) 1976年（昭和51年）9月 } \\
\text { 望月 巧一 }\end{array}$ \\
\hline 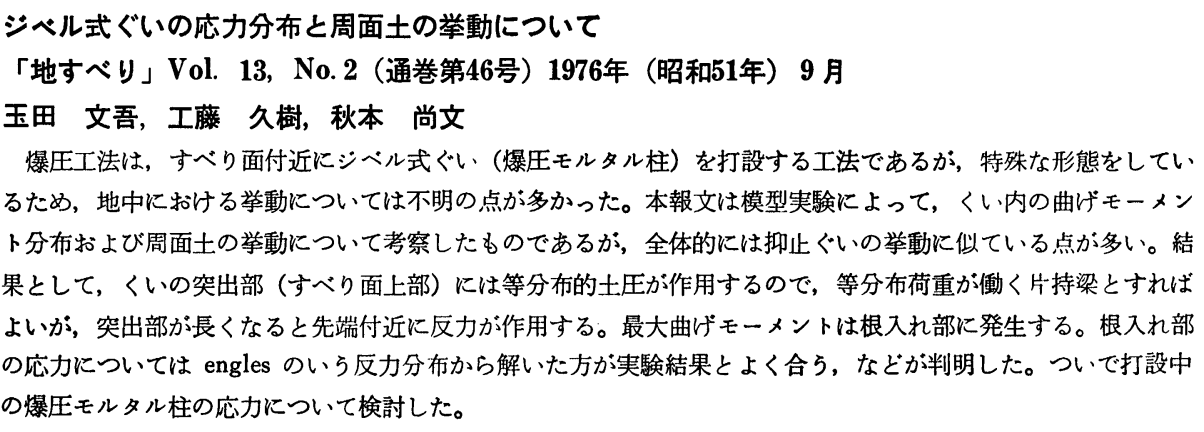 \\
\hline 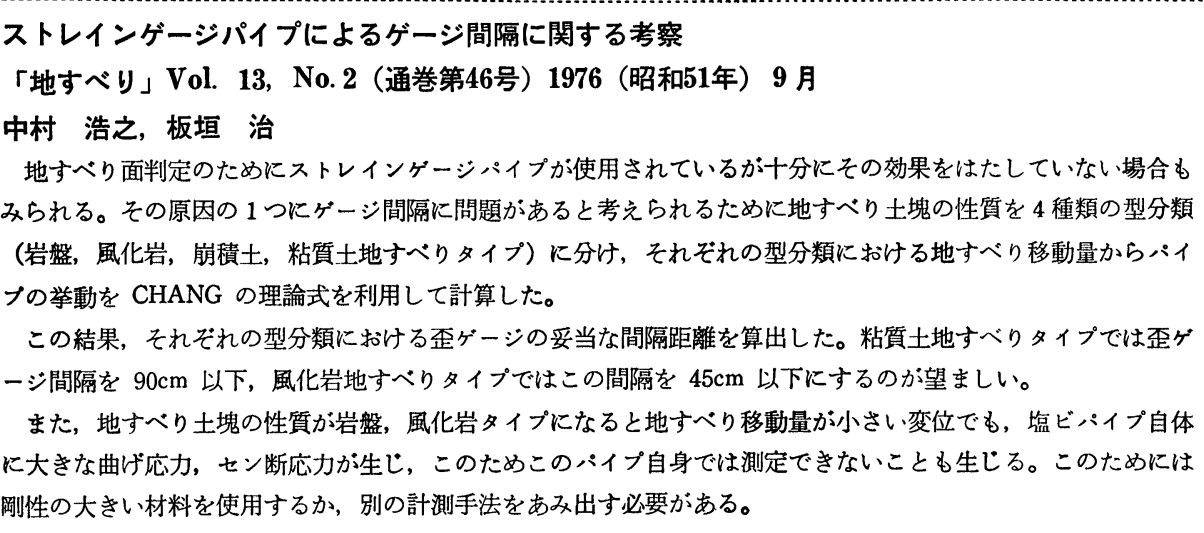 \\
\hline 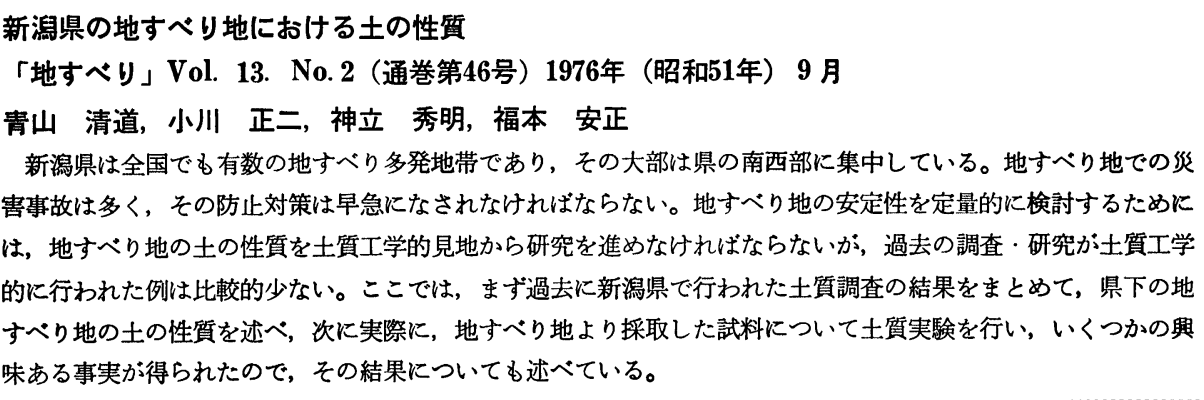 \\
\hline 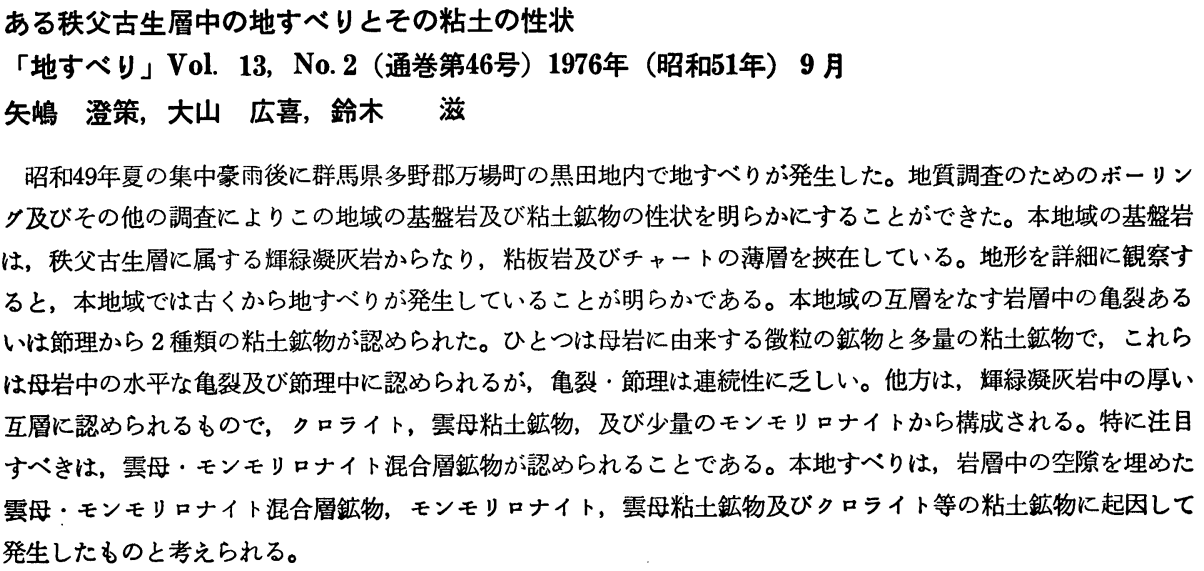 \\
\hline
\end{tabular}

